\title{
PERSUATION COMMUNICATION ON HEALTHY AND CLEAN LIFE BEHAVIOR IN THE SOCIETY
}

\author{
Nawiroh Vera ${ }^{1 *}$, Benny Muhdaliha ${ }^{1}$ \\ Communication Faculty, Budi Luhur University \\ *nawiroh.vera@budiluhur.ac.id
}

\begin{abstract}
Clean and Healthy Life Behavior (PHBS) in the Household is an effort to empower family members to know, want and be able to apply clean and healthy behavior and play an active role in the health movement in the community. The application of PHBS in the household is the responsibility each of family member, which is also the responsibility of the government / city along with the relevant sectors to facilitate PHBS activities in the household so that it can be carried out effectively. Our community service team from Budi Luhur University became facilitators to provide support of socialize about clean and healthy environment for residents in Sudimara Jaya Village, Ciledug District. After mentoring on waste management and beautifying the environment by decorating the walls with murals, the environment in the RW07 Sudimara Jaya Ciledug area became a clean, healthy and beautiful environment.
\end{abstract}

Keywords: Environment, clean, healthy, persuasive communication

\section{INTRODUCTION}

Clean and Healthy Life Behavior (PHBS) are all health behaviors that are carried out consciously so that family members can help themselves in the health sector and play an active role in health activities in the society.Clean and Healthy Behavior (PHBS) in the Household is an effort to empower household members to know, want and be able to practice clean and healthy life behavior and play an active role in the health movement in the community. PHBS (PerilakuHidupBersihdanSehat) in the Household is carried out to reach the Household with a clean and healthy lifestyle. A person's clean and healthy life behavior is related to improving the health of individuals, families, communities and their environment (http://promkes.depkes.go.id)

Households with PHBS means being able to maintain, improve and protect the health of each household member from disruption of disease threats and a less conductive environment for healthy living.The application of PHBS in the household is the responsibility of each household member, which is also the responsibility of the government / city along with the relevant sectors to facilitate PHBS activities in the household so that it can be carried out effectively.Observations result show that the neighborhood of RW 07 in Sudimara Jaya Sub-District, CiledugSubdistrict is a densely populated environment, most of the residential areas are rented, and the level of environmental cleanliness is still quite low. This is indicated by the number of unorganized garbage stacks, blocked gutters, stinging stench along the road, and other problems. This area have many children under five years old and elementary school age which is that age very vulnerable to diseases and Dengue Fever that can be outbreaks because of the low understanding of the community about a clean and healthy environment, especially the low awareness of throwing garbage in its place.

Garbage and its management are now becoming an increasingly urgent problem in cities and villages in Indonesia, because if poor handling is carried out it will lead to changes in the environmental balance that is detrimental or not expected to pollute the environment, both to land, water and air. Therefore, to overcome the pollution problem, it is necessary to handle and control waste. Handling and controlling will become increasingly complex and complicated by the increasingly complex types and composition of waste in line with the advancement of culture (Chandra, 2006: 122).Clean and Healthy Life Behavior is one of the strategies that can be taken to produce independence in the health 
sector both for the society and for families. This means that there must be communication between the cadre and the family / society to provide information and conduct health education.

The right form of communication is persuasive communication, namely "communication methods that are subtle persuasion so that the target becomes confident" usually in the form of an invitation by giving reasons and good prospects that are convincing (Uripni et al, 2002: 14). The term persuasive itself is a message that is inviting how audiences want to carry out the message purpose (Muhith\&Siyoto, 2018: 182).Based on the description above, there is a need for ongoing attention and understanding of hygiene and environmental health through mentoring activities in order to achieve the goals of clean and healthy behaviors, which include providing training on waste management. Waste management that meets health requirements so that it becomes one of the activities in the community in an effort to prevent various diseases due to not behaving in a clean and healthy life.In addition to waste management also about the beauty of the environment to be comfortable. The walls of the house that contain idle scribbles / vandalism were cleaned and replaced with attractive murals.

Based ofthe background, focus in this activity will be to plan and provide guidance on clean and healthy living in the neighborhood of RW 07 in Sudimara Jaya Sub-district, Ciledug Sub-District, Tangerang through training in waste management and mural making. This service is expected to provide benefits, namely increasing the knowledge gained by local residents about the need for clean and healthy living, and the changing of the slum environment into a clean, beautiful, comfortable environment.

\section{Society Profile}

The target area of this service is the environment in RW07, Sudimara Jaya, Ciledug District, Tangerang City. RW07 consists of seven RTs. Around the target area there are several places of business including Meatballs, Laundry, and Warehouse for sale of packaged beverages. In addition there are also many rented houses inhabited by migrants from Central and West Java.

\section{Conditions of the Society Service Activities}

At present the condition of the area in RW07 in the whole of Sudimara Jaya in CiledugSubdistrict is quite poor, a lack of awareness of the community towards the environment, plus the presence of micro industries around resident areas. that why, we, from the Budi Luhur University, want to work together with the Sudimara peoples and the administrative component in the area to assist the need for clean and healthy living.

\section{METHOD}

Community service was carried out in Ciledug, Sudimara Jaya Subdistrict, precisely carried out in the RW002 area. base on the problems and conditions of the area, this community service carries several activities, that is;

- Helping the chief of the Posyandu, PKK and KarangTaruna in the neighborhood RW07, Sudimara Jaya village, to make a regulatory plan, which will be applied in the RW 07 area.

- Conduct PHBS socialization and prevention of infectious diseases in this environment.

- Providing workshops on beautiful green environments by getting used to processing waste and planting trees in their homes.

- Providing training in making murals in a residential area

Activity materials are made in the form of hand outs. the design of programs guide book take of the form of presentation slide as consideration to make it easier for target society to understand the material presented. the subject of presentation delivered in the language of communication and simulation and case studies. Activities are divided into planning stages, implementation stages, and evaluation stages. 


\section{RESULT AND DISCUSSION}

This Community Service activity carried out by the Faculty of Communication University Budi Luhur University lecturers and students with theme "persuasion communication about clean and healthy living behavior in the community" this theme is considered suitable because the target society in Community Service activities are residents in RW 07 KelurahanSudimara Jaya Ciledug is the father, mother and Youth Organization is quite active. There are several reasons for choosing this theme, first, the existence of a grant from the Tangerang local government to RW 07 in Sudimara Jaya village, namely Clean and Healthy Behavior Grant. this grants are given to villages or regions that are considered not optimal in applying a clean and healthy lifestyle.

As a dedication in implementing the Tridharma of Higher Education, we are a team of lecturers Budi Luhur University feel we must help the Sudimara peoples by providing assistance to the residents in RW 07 Sudimara Jaya in implementing the PHBS program. Based on these considerations, the implementing team decided that the activities carried out were socialization of clean and healthy lifestyles to all residents in RW 07 Sudimara Jaya Ciledug. Providing training in managing waste banks, and training youth and KarangTaruna in creating Murals to beautify Kampung in the RW 07 area.

The target for the implementation of this Community Service activities has been achieved, with continual event meetings by all residents of RW 07 Sudimara Jaya which active in the socialization and training of PHBS. Also had created an environment with various murals designed to make the environment more beautiful and unsightly.Socialization and training efforts are carried out through material briefing delivered through two-way communication. Besides being supported by presentation with attractive images. The material presented is not only related to the importance of clean and healthy life, but also the material on the importance of keeping the environment in order to remain neatly organized.

\section{Discussion}

The initial stage of the implementation was discussion the implementable method of socialization strategy that agreed upon between the Team from Budi Luhur University and the Posyandu, Kelurahan, and KarangTaruna RW 07 KelurahanSudimara Jaya, Ciledug District.

the second stage is the socialization of PHBS and the Waste Bank to the local residents. The activity was attended by the majority of woman who were very enthusiastic and committed to implementing a clean and healthy environment.

Village decorating activities with murals are in great demand by local teenagers. Students who are members of the Gradasi community in collaboration with the local Youth Organization beautify the walls that are usually doodled into mural images that contain moral messages and the invitation to clean and healthy life.Mural is a variety of visual communication. The definition of visual communication is "a design that communicates information and messages that are displayed visually" (Cenadi 1999 in Fitriah 2018: 16). Understanding murals is "how to draw or paint on the walls of walls, walls, or other large permanent surfaces (Kusrianto, 2010: 19)
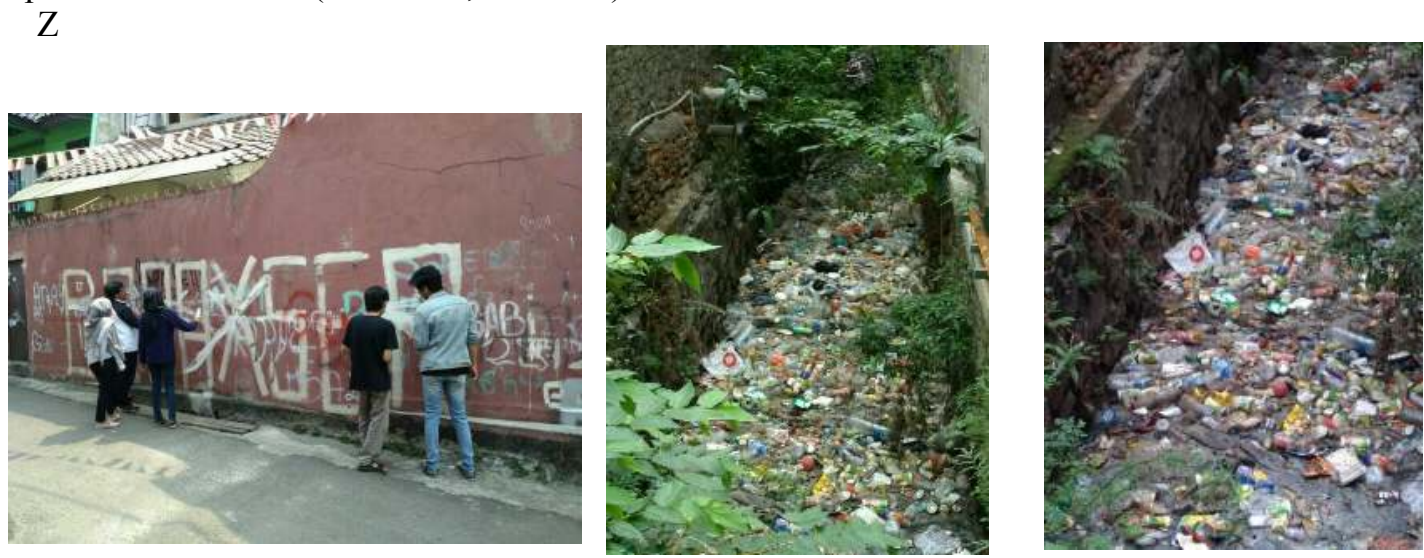

Figure 1. The resident areas in Sudimaras before the programs 


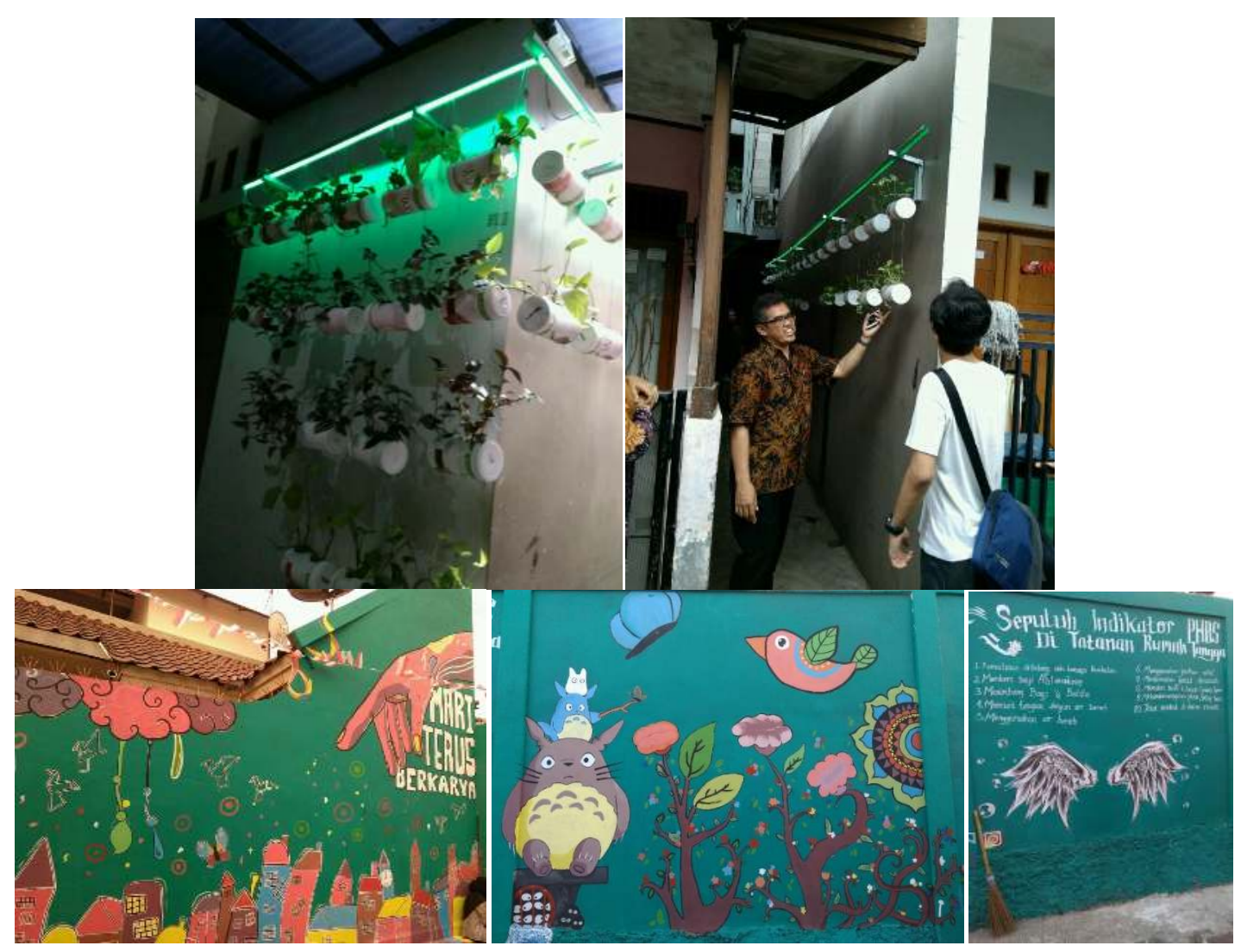

Figure 2. The result after the programs

\section{CONCLUSION}

The cleanliness is a part of faith is a hadith that encourages every Muslim in particular and all humans to always maintain cleanliness. Cleanliness starts from ourselves, the household, and the environment around us. The government's Clean and Healthy Behavior grant program is truly a manifestation of the Tangerang City Regional Government's concern for the cleanliness and health of residents in the area.In 2017 RW 07 Sudimara Jaya Village received a PHBS Grant, we as local residents and at the same time as a lecturers at Budi Luhur University were moved to help the local community in the implementation of this grant. Alhamdulillah, the initial stage was successfully implemented, namely socialization and beautifying the village with murals. The next stage we will assist in managing the waste bank.

\section{REFERENCE}

Chandra, B. (2006). Pengantar Kesehatan Lingkungan. EGC. Jakarta.

Fitriah, M. (2018). Komunikasi Pemasaran Melalui Desain Visual. Yogyakarta: deepublish.

Kusrianto, A. (2010). Pengantar Tipografi. Jakarta: PT Elek Media Komputindo.

Muhith, A \& Siyoto, S. 2018. Aplikasi Komunikasi Teraputik Nursing \& Health. Yogyakarta: Andi

Uripni, C. L \& et al. (2002). Komunikasi Kebidanan. Jakarta: penerbit buku kedokteran EGC

http://promkes.depkes.go.id/wpcontent/uploads/pdf/buku_pedoman/booklet\%20phbs\%20rumah\%20ta ngga.pdf 